\title{
EPIDEMIOLOGICAL SURVEY OF LEISHMANIASIS USING SKIN TEST AND ELISA IN ECUADOR
}

\author{
Masato Furuya ${ }^{1}$, TATSUYuki Mimori ${ }^{2}$, Eduardo A. Gomez L. ${ }^{3}$, \\ Vicenta Vera de CoRonel ${ }^{3}$, Masato Kawabata ${ }^{4}$ and Yoshinisa Hashiguchi ${ }^{5}$ \\ Received June 8 1989/Accepted October 71989
}

\begin{abstract}
The present study was designed to evaluate the intradermal skin test (ST) and the ELISA as diagnostic tools in the screening for Ecuadorian cutaneous and mucocutaneous leishmaniasis. The antigen for skin testing was prepared from ruptured promastigotes of Leishmania braziliensis. The ST and ELISA positive rates among 72 subjects with active dermal lesions were $81.8 \%(36 / 44)$ and $81.3 \%(52 / 64)$, respectively, while parasites were observed in $31(44.9 \%)$ of 69 subjects presenting active lesions. In the parasites positive cases, all subjects proved to be positive for the two tests except for one in ST and two in ELISA. In 35 healed cases, the ST and ELISA positive rates were $86.2 \%$ $(25 / 29)$ and $72.4 \%(21 / 29)$, respectively. On the other hand, the positive rate in subjects without clinical signs was only $3.8 \%$ in ST and $8.2 \%$ in ELISA. An epidemiological survey in Selva Alegre, Esmeraldas, revealed that among 115 inhabitants 38 were positive for the clinical signs, 10 active and 28 healed cases. Of these subjects $33(86.8 \%)$ showed positive reactions against ST and/or ELISA. Based on the results obtained, therefore, we concluded that the present skin testing antigen and ELISA were very useful for the screening of leishmaniasis in the endemic areas of Ecuador.
\end{abstract}

\section{INTRODUCTION}

Since the first human case of leishmaniasis was described in Ecuador in 1920, many. additional cases of the disease have been reported (Rodriguez, 1974; Hashiguchi et al., 1984). The causative agent has been considered L. braziliensis complex based mainly on their clinical manifestations in humans and epidemiological features (Rodriguez, 1974). Recently, we characterized six strains of Leishmania isolates in Ecuador, using isoenzyme electrophoresis and monoclonal antibodies. Three strains, isolated from cutaneous lesions of humans, were identified as $L . b$. panamensis, while the remainings from wild animals were identified as L. mexicana amazonensis (Mimori et al., 1989). Thus, the species of Leishmania most commonly found in our study areas endemic for leishmaniasis in humans was considered to

1 Institute for Laboratory Animals, Kochi Medical School, Kochi 781-51, Japan

2 Department of Parasitic Diseases, School of Medicine, Kumamoto University, Kumamoto 860, Japan

3 Departamento de Parasitologia, Instituto Nacional de Higiene y Medicina Tropical, Apartado 3961, Guayaquil, Ecuador

4 Department of Clinical Pathology, School of Medicine, Nihon University, Tokyo 173, Japan

5 Department of Parasitology, Kochi Medical School, Kochi 781-51, Japan 
be $L$. braziliensis complex.

Little information, on the other hand, has been available on epidemiological features of the disease in this country (Hashiguchi et al., 1984). Such insufficient epidemiological information has partly been due to the lack of reliable diagnostic tool in field studies. Recently, it has been reported that a soluble leishmanial extract prepared from $L$. donovani chagasi promastigotes was highly sensitive and specific for an intradermal skin test for American visceral leishmaniasis patients (Reed et al., 1986). In order to obtain a better understanding of the epidemiology of leishmaniasis in Ecuador, we therefore designed a preliminary survey to evaluate a similarly prepared skin testing antigen.

The present paper deals with the finding that the soluble antigen prepared from $L$. braziliensis promastigotes can be readily employed in skin testing for the screening of cutaneous and mucocutaneous leishmaniasis in areas of Ecuador endemic for these diseases.

\section{Materials ANd Methods}

\section{Study areas and subjects}

The present examinations were carried out during the dry season from July to August, 1986 in Ecuador. A preliminary study using skin test (ST) and enzyme-linked immunosorbent assay (ELISA) was made on 63 subjects with active dermal lesions who visited the Instituto Nacional de Higiene y Medicina Tropical (INHMT), Guayaquil, and rural health centers and hospitals in several endemic areas of Ecuador. An epidemiological survey was conducted on 115 inhabitants in Selva Alegre, Esmeraldas, Ecuador by performing ST and ELISA. Thirty four school children in Gramalote Chico, Los Rios, were also examined by ST alone. Thus, a total of 212 subjects were tested by leishmanial ST and/or ELISA in this study.

ELISA

L. b. braziliensis (MHOM/BR/75/M 2904) obtained from Dr. P. Desjeux, PDP, WHO (formerly Instituto Boliviano de Biologia de Altura, Bolivia) was cultured with Pan's medium (Pan, 1984). Soluble extract prepared from the harvested promastigotes was used as an antigen. The ELISA procedure was performed according to the method described by Mimori et al. (1987). All the serum samples tested were diluted 1:10. Absorbance values of more than OD 0.25 at $500 \mathrm{~nm}$ were employed as criteria for evaluating positive serum, since the absorbances in tested control sera from 66 healthy individuals in Ecuador were less than OD 0.25 .

Intradermal skin test

A soluble antigen used for skin testing in this study was prepared by the method of Reed et al. (1986). The promastigotes of $L$. braziliensis were harvested and washed five times with a balanced salt solution. After the final washing the parasite pellet was resuspended in 5 volumes of distiled water, and a freeze-thawing procedure with aceton-dry ice and tepid water was repeated 10 times. The disruped parasites were diluted in PBS and centrifuged at $10,000 \times \mathrm{g}$ for $30 \mathrm{~min}$ at $4^{\circ} \mathrm{C}$. The supernatant was adjusted to $250 \mu \mathrm{g}$ protein concentration per $\mathrm{m} l$ before filtration with a $0.45 \mu$ sterile filter. One-tenth $\mathrm{m} l$ of the antigen solution was injected intradermally in the flexor surface of the forearm. Induration size of more than $5 \mathrm{~mm}$ at the site 48 hours after the injection was considered to be a positive reaction based on the criteria employed by Reed et al. (1986). 
Biopsy smear specimens

Smear samples were taken from the margin of ulcerated lesions, stained with Giemsa or Wright solutions, and examined with an oil immersion objective. At least 100 fields were examined.

\section{RESULTS}

In our initial study, an evaluation of ST and ELISA was made on 63 subjects with active dermal lesions who visited INHMT, rural health centers and hospitals in Ecuador (Table 1). In this case $45.5 \%$ were positive for leishmanial amastigotes in smear specimens. The ST and ELISA positive rates were significantly high in the parasite positive group compared with the parasite negative one $(P<0.1$ in ST, $P<0.05$ in ELISA, and $P<0.05$ in the both tests). However, a relatively high positive rate for ST and ELISA was observed in the parasite negatives. This high rate suggests that a considerable number of true leishmanial patients may be included in those parasite negatives. No significant difference in average induration size between parasite positives $(17.4 \pm 9.0)$ and negatives $(13.6 \pm 5.7)$ was observed. These data indicate that the ST and ELISA are very suitable tools in the screening of Ecuadorian leishmaniasis.

Using these diagnostic tools, an epidemiological survey was conducted in Selva Alegre, Esmeraldas (Table 2). Of 115 subjects examined dermatologically for leishmanial ulcers, nodules and scars, 10 active and 24 of 28 healed cases were discovered from the physical examination and interview prior to the skin testing. The remaining 4 of the healed cases were detected by re-examination after these had shown ST-positive results. All the leishmanial scars in such cases were observed on the usually unexposed areas of the body. We went through the same experience in another endemic area, Gramalote Chico, Los Rios. In the survey, typical leishmanial scars were confirmed in 6 out of 8 ST-positives among 34 examinees after skin testing.

In Selva Alegre, a parasitological examination was performed on 7 out of 10 subjects with active dermal lesions. Only one patient was positive for leishmanial amastigotes, and he also showed positive responses to ST and ELISA. The ST and ELISA positive rates among these subjects were $80.0 \%(8 / 10)$ and $66.7 \%(6 / 9)$, respectively. In the subjects with healed dermal lesions, the positive ST and ELISA rates were $79.2 \%(19 / 24)$ and $71.4 \%$

Table 1 Results of a preliminary evaluation of intradermal skin test and ELISA in 63 subjects with active cutaneous (leishmanial) lesion in Ecuador

\begin{tabular}{|c|c|c|c|c|c|}
\hline \multirow[b]{2}{*}{$\begin{array}{l}\text { Smear } \\
\text { specimens* }\end{array}$} & \multicolumn{2}{|c|}{ No. examined } & \multicolumn{3}{|c|}{ Positive rate per examinees $\dagger$} \\
\hline & $\begin{array}{c}\text { female } \\
\text { (age) }\end{array}$ & $\begin{array}{l}\text { male } \\
\text { (age) }\end{array}$ & skin test & ELISA & skin test \& ELISA \\
\hline+ & $\begin{array}{c}14 \\
(2-66)\end{array}$ & $\begin{array}{c}16 \\
(1-66)\end{array}$ & $93.3(14 / 15)$ & $92.3(24 / 26)$ & $90.9(10 / 11)$ \\
\hline- & $\begin{array}{c}18 \\
(1-66)\end{array}$ & $\begin{array}{c}15 \\
(7-61)\end{array}$ & $73.7(14 / 19)$ & $75.7(22 / 29)$ & $56.3(9 / 16)$ \\
\hline Total & 32 & 31 & $82.4(28 / 34)$ & $83.6(46 / 55)$ & $70.4(19 / 27)$ \\
\hline
\end{tabular}

"Materials from ulcer lesions were fixed, stained and then examined microscopically.

$\dagger$ Examinees were not the same number in each test, mainly because of follow-up difficulties. 
Table 2 Correlation between clinical diagnosis and immunodiagnosis in 115 inhabitants in Selva Alegre, Esmeraldas, Ecuador, using skin test and ELISA

\begin{tabular}{|c|c|c|c|c|c|}
\hline \multicolumn{2}{|c|}{ Reaction to } & \multicolumn{2}{|c|}{ No. with signs } & \multirow{2}{*}{$\begin{array}{l}\text { No. } \\
\text { without } \\
\text { signs }\end{array}$} & \multirow{2}{*}{ Total } \\
\hline skin test & ELISA & active* & healed $t$ & & \\
\hline+ & + & 5 & 15 & & 20 \\
\hline+ & - & 2 & 4 & 2 & 8 \\
\hline- & + & 1 & 1 & 6 & 8 \\
\hline- & - & 1 & 4 & 64 & 69 \\
\hline \multicolumn{2}{|c|}{ (sub-total) } & 9 & 24 & 72 & 105 \\
\hline+ & ND & 1 & & & 1 \\
\hline ND & + & & 4 & & 4 \\
\hline- & ND & & & 4 & 4 \\
\hline ND & - & & & 1 & 1 \\
\hline \multicolumn{2}{|c|}{ (sub-total) } & 1 & 4 & 5 & 10 \\
\hline \multicolumn{2}{|c|}{ Total } & 10 & 28 & 77 & 115 \\
\hline
\end{tabular}

*Persons with leishmanial ulcers.

†Persons with leishmanial scars.

$¥$ Not done.

Table 3 Summary of the results of clinical, parasitological and immunological examinations in 212 subjects in Ecuador

\begin{tabular}{|c|c|c|c|c|c|c|c|}
\hline \multirow{2}{*}{\multicolumn{2}{|c|}{ Reaction to }} & \multicolumn{4}{|c|}{ No. with signs } & \multirow{4}{*}{$\begin{array}{l}\text { No. } \\
\text { without } \\
\text { signs }\end{array}$} & \multirow{4}{*}{ Total } \\
\hline & & & ctiv & & healed $t$ & & \\
\hline \multirow{2}{*}{$\begin{array}{l}\text { skin } \\
\text { test }\end{array}$} & \multirow[t]{2}{*}{ ELISA } & \multicolumn{3}{|c|}{ smear specimens $\ddagger$} & & & \\
\hline & & + & - & NDई & & & \\
\hline+ & + & 11 & 12 & 1 & 15 & & 39 \\
\hline+ & - & & 4 & & 4 & 2 & 10 \\
\hline- & + & 1 & 5 & 1 & & 6 & 13 \\
\hline- & - & & & 1 & 4 & 64 & 69 \\
\hline \multicolumn{2}{|c|}{ (sub-total) } & 12 & 21 & 3 & 23 & 72 & 131 \\
\hline+ & ND§ & 4 & 4 & & 6 & 2 & 16 \\
\hline ND & + & 13 & 8 & & 6 & & 27 \\
\hline- & ND & & & & & 30 & 30 \\
\hline ND & - & 2 & 5 & & & 1 & 8 \\
\hline \multicolumn{2}{|c|}{ (sub-total) } & 19 & 17 & & 12 & 33 & 81 \\
\hline \multicolumn{2}{|c|}{ Total } & 31 & 38 & 3 & 35 & 105 & 212 \\
\hline
\end{tabular}

*Persons with leishmanial ulcers.

†Persons with leishmanial scars.

$\ddagger$ Materials from ulcer lesions were fixed, stained and then examined microscopically.

$\S$ Not done. 
Table 4 Frequency distribution of induration size in leishmanial skin test positive subjects with active or healed cutaneous (leishmanial) lesions

\begin{tabular}{ccccccc}
\hline \multirow{2}{*}{$\begin{array}{c}\text { Induration } \\
\text { size }(\mathrm{mm})\end{array}$} & $\begin{array}{l}\text { No. } \\
\text { positive } \\
\text { subjects }\end{array}$ & \multicolumn{2}{c}{ Active lesions } & & \multicolumn{2}{c}{ Healed lesions } \\
\cline { 7 - 7 } \cline { 6 - 7 } & 11 & 9 & $\%$ & & No. & $\%$ \\
\hline $5-10$ & 10 & 10 & 25.0 & 2 & 8.0 \\
$11-15$ & 18 & 7 & 19.4 & & 11 & 44.0 \\
$16-20$ & 16 & 6 & 16.7 & & 10 & 40.0 \\
$21-25$ & 2 & 2 & 5.6 & & \\
$26-30$ & 4 & 2 & 5.6 & & 8.0 \\
$\geqq 31$ & & & & &
\end{tabular}

$(20 / 28)$, respectively. Twenty subjects who showed positive reactions for both tests had either active or healed lesions. It was found that five subjects with those signs were negative for both the ST and ELISA, while eight without active or healed lesions were positive for one of the two tests. Coincidence rates of ST and ELISA among 105 subjects, 33 with and 72 without the signs, who received both tests in Selva Alegre, were as follows: both positive, $19.0 \%$; both negative, $65.7 \%$; and positive against one of the two, $7.5 \%$.

Table 3 summarizes the results of clinical, parasitological and immunological examinations of 212 examinees in the current study. Coincidence rates between both tests among 59 subjects who had clinical signs and received the two tests were as follows: positive and negative for the two tests, $66.1 \%$ and $8.5 \%$, respectively; positive against one of the two, $13.5 \%$ in ST and $11.9 \%$ in ELISA. Furthermore, 64 (88.9\%) out of 72 subjects who had no clinical signs and received the two tests did not react against these tests, completely. Thus, a close agreement between dermal clinical signs and immunodiagnosis was demonstrated with a few exceptions.

Frequency distribution of the ST induration size in positive subjects with active or healed dermal lesions is summarized in Table 4. Average induration size was $15.7 \pm 7.7$ in active, and $20.0 \pm 5.4$ in healed cases. The size was significantly different between both cases $(P<0.05)$, showing a strong ST reaction in the healed one. No significant difference was found in the induration size between the patients with active and healed cutaneous lesions, when considered with regard to either sex or age.

\section{DisCUSSION}

The present study was carried out to evaluate two immunodiagnostic tools, ST and ELISA, in the screening of cutaneous leishmaniasis in the endemic areas of Ecuador. In the epidemiological survey in endemic areas, a presumptive diagnosis is often made on the basis of clinical diagnosis and Montenegro skin test (Mayrink et al., 1979; Werner and Barreto, 1981). A definitive diagnosis of leishmaniasis requires demonstration of the etiologic agent from the lesions. However, the visualization of protozoa in tissue samples and the isolation of parasites from active lesions by culture methods were fraught with difficulties. Weigle $e t$ al. (1987) recommended two diagnostic procedures based on their studies, i.e., dermal scraping smears for immediate diagnosis and culture of aspirates for a definitive para- 
sitological diagnosis of cutaneous lesions. In the present survey, parasites were observed in $31(44.4 \%)$ of 69 subjects presenting active lesions (Table 3 ).

As shown in Table 3, ST-positive rate was $81.8 \%(36 / 44)$ of the total skin tested examinees with active lesions. In the parasite positive cases, furthermore, all subjects but one proved to be positive for the ST. On the other hand, the positive rate in subjects without clinial signs was only $3.8 \%(4 / 104)$. It is well recognized that the immunological methods, especially ST and ELISA, are useful tools for diagnosis of New World cutaneous leishmaniasis (Bray, 1980). The reliability of these tests, however, has been hampered by the problem of cross reactivity with various species within the family, Trypanosomatidae, as well as with other microorganisms such as mycobacteria (Mauel and Behin, 1982). We have no data with regard to cross reactivity of the present $L$. braziliensis antigen preparation. Reed et al. (1986), however, reported that their similarly prepared $L . d$. chagasi-soluble extract produced no positive responses in either normal controls, tuberculosis patients, or schistosomiasis patients, and less than 5\% positive responses in persons with Chagas' disease. From this information and our results, it is assumed that the present preparation also shows a lesser degree of cross reactivity.

Table 3 suggests that there may be close agreement between clinical signs and results of immunodiagnosis, except for 12 subjects in Selva Alegre and 2 in Glamalote Chico. Four subjects in Selva Alegre, showing negative reactions against both tests, may have had other dermatological lesions mistaken for leishmanial scars. The remaining cases suggest the possibility of either cross-reactions with other infectious agents or oversight of leishmanial lesions.

Diagnosis using ST and ELISA is commonly used against New World cutaneous leishmaniasis. However, the standardization of skin test antigen has not yet been done sufficiently to have a satisfactory results. In this paper, we evaluated the soluble extract obtained by the method of Reed et al. (1986) from ruptured L. braziliensis promastigotes, as a ST antigen. Our results obtained showed that the extract was found to be highly sensitive and specific against Ecuadorian cutaneous and mucocutaneous leishmaniasis patients. It was concluded that the use of the present ST, together with ELISA, would be useful in diagnosis for patients with active and healed leishmanial lesions in the endemic areas of the disease.

\section{ACKNOWLEDGEMENTS}

We express our heartfelt thanks to Dr. F. Parra Gil, Director of the INHMT, Guayaquil, Ecuador, and also express our appreciation to Dr. S.G. Reed of Seattle Biomedical Research Institute, U.S.A. for critical reading of the manuscript. We are much indebted to all the members of the Departamento de Parasitologia, INHMT, for their support. We are extremely grateful to Dr. P. Desjeux of PDP, WHO (formerly Instituto Boliviano de Biologia de Altura, Embajada de Francia, Bolivia) for his generous supply of Leishmania reference strains.

This study was supported by the Grant-in-Aid for Overseas Scientific Research of the Ministry of Education, Science and Culture, Japan (Nos. 61041059 and 62043055) 


\section{REFERENCES}

1) Bray, R.S. (1980): Leishmaniasis, In: Immunological investigation of tropical diseases, ed. by Houba, S.V., 65-74, Churchill-Livingstone, Edinburgh

2) Hashiguchi, Y., Coronel, V.V. and Gomez, E.A.L. (1984): An epidemiological study of leishmaniasis in a plantation "Cooperativa 23 de Febrero" newly established in Ecuador, Jpn. J. Parasitol., 33 (5) , 393-401

3) Mauel, J. and Behin, R. (1982): Leishmaniasis: Immunity, immunopathology and immunodiagnosis, In: Immunology of parasitic infections, ed. by Cohen, S. \& Warren, K., 2nd ed., 299-355, Blackwell Scientific, Oxford

4 ) Mayrink, W., Williams, P., Coelho, M.V., Dias, M., Martins, A.V., Magalhaes, P.A., DaCosta, C.A., Folcoa, A.R., Melo, M.N. and Falcao, A.L. (1979): Epidemiology of dermal leishmaniasis in the Rio Doce Valley, State of Minas Gerais, Brazil, Ann. Trop. Med. Parasit., 73 (2), 123-137

5 ) Mimori, T., Grimaldi, G.Jr., Kreutzer, R.D., Gomez, E.A.L., McMahon-Pratt, D., Tesh, R.B. and Hashiguchi, Y. (1989): Identification of Leishmania isolated from humans and wild animals in Ecuador, using isoenzyme electrophoresis and monoclonal antibodies, Am. J. Trop. Med. Hyg., 40(1), $156-160$

6) Mimori, T., Hashiguchi, Y., Kawabata, M., Gomez, E.A.L. and Coronel, V.V. (1987): The relationship between severity of ulcerated lesions and immune responses in the early stage of cutaneous leishmaniasis in Ecuador, Ann. Trop. Med. Parasit., 81 (6), 681-685

7 ) Pan, A.A. (1984): Leishmania mexicana: Serial cultivation of intracellular stages in a cell-free medium, Exp. Parasitol., 58(1), 72-80

8 ) Reed, S.G., Badaro, R., Masur, H., Carvalho, E.M., Lorenco, R., Lisboa, A., Teixeira, R., Johnson, W.D.Jr. and Jones, T.C. (1986): Selection of a skin test antigen for American visceral leishmaniasis, Am. J. Trop. Med. Hyg., 35(1), 79-85

9 ) Rodriguez, J.D.M. (1974): Genero Leishmania, In: Lecciones de Parasitologia Humana, 5th ed., 170-185, Universidad de Guayaquil, Guayaquil, Ecuador

10) Weigle, K.A., Davalos, M., Heredia, P., Molineros, R., Saravia, N.G. and D'Alessandro, A. (1987): Diagnosis of cutaneous and mucocutaneous leishmaniasis in Colombia: A comparison of seven methods, Am. J. Trop. Med. Hyg., 36 (3), 489-496

11) Werner, J.K. and Barreto, P. (1981): Leishmaniasis in Colombia: A review, Am. J. Trop. Med. Hyg., 30(4), 751-761 
南米エクアドル共和国リーシュマニア症の皮内反応と ELISA 法による疫学調査

古谷 正人・三森 龍之・E.A.L. Gomez
V.V. Coronel ・川端 真人・橋口 義久

南米エクアドル共和国における, 皮膚型および皮虐粘膜型リーシュマニア症の疫学調査での皮 内反応 (ST)，およびELISA 法の有用性について検討した結果を報告する。

. 皮内反応抗原は, Leishmania braziliensis promastigote 型原虫から作成した。潰瘍病変 (leishmanial ulcers）保有者72名におけるST と ELISA の陽性率は, それぞれ81.8\%（36/44）および 81.3\% (52/64) であった。これらの患者の内, 原虫が認められた者は検查が実施できた69名中 31 名 (44.9\%)であった。原虫が証明された患者において, ST で1名, ELISA で2名が陰性であっ た以外は，全ての者が両検査に陽性であった。治癒病変（leishmanial scars）保有者35名におけ る ST と ELISA の陽性率は, それぞれ86.2\% (25/29) と72.4\% (21/29) であった。一方, 病変 が認められない者におけるST と ELISA の陽性率は，3.8\%（ST) および8.2\% (ELISA) と非 常に低率であった。

同国 Esmeraldas 地方の Selva Alegre 村で, リーシュマニア症の罹患状況を調べた。その結 果, 115名中 38 名に何らかの病変 (潰瘍病変 10 名・治癒病変 28 名) が認められ, その内の 33 名 $(86.8 \%$ ) がST と ELISA 両検查法に陽性であった。

以上の結果から, 同国リーシュマニア症流行地域での疫学調査に, 今回の両検查法が有効であ ることが示された。 